\title{
Characterization of provincially inspected slaughterhouse wastewater in Ontario, Canada
}

\author{
P.F. $\mathrm{Wu}^{1}$ and G.S. Mittal ${ }^{1 *}$ \\ ${ }^{1}$ School of Engineering, University of Guelph, Guelph, Ontario, Canada, N1G $2 \mathrm{~W} 1$. \\ *Email: gmittal@uoguelph.ca
}

Wu, P.F. and G.S. Mittal. 2012. Characterization of provincially inspected slaughterhouse wastewater in Ontario, Canada. Canadian Biosystems Engineering/Le ge' nie des biosyste' mes au Canada. 54: 6.9-6.18. Characteristics of slaughterhouse waste-water and its suitability to be land-applied for agricultural use were investigated. A survey was sent to slaughterhouses located in Ontario, Canada, and their methods of disposal were determined. Wastewater samples were taken from randomly selected slaughterhouses and were analyzed for their chemical constituents. The meat type, presence of blood and the commodity type had a highly significant impact on the biological oxygen demand (BOD5), total Kjeldahl nitrogen (TKN) and total solids (TS). As TKN and BOD5 can be decreased by the reduction of TS in the wastewater, it is important that the slaughterhouses remove as much TS from the wastewater as possible. The presence of blood increased $\mathrm{Co}$ and Mo levels in the wastewater. The concentrations of 11 metals present are very low and if the wastewater is land applied properly, the risk to the environment is minimal. Keywords: Abattoir, land application, meat plant, slaughterhouse, wastewater.

Cette 'etude a porte' sur les proprie' te' $\mathrm{s}$ des eaux use' es d'abattoirs et sur la possibilite' d'e' pandre ces eaux sur des terres agricoles. Un sondage a $\mathrm{e}^{\prime} \mathrm{te}^{\prime}$ envoye' 'a tous les abattoirs situe' $\mathrm{s}$ e $\mathrm{n}$ Ontario, Canada dans le but de de' terminer les me' thodes utilise' es pour la disposition de leurs eaux use' es. Des e' chantillons d'eaux use' es ont e' te' pre' leve' s a 'un certain nombre d'abattoirs choisis de fac, on ale' atoire dans le but de de' terminer leur composition chimique. Le type de viande, la pre' sence de sang et le type d'animal ont tous eu un impact tre's significatif sur la demande en oxyge' ne biologique (BOD5), l'azote total Kjeldahl (TKN) et les solides totaux (TS). Puisque la TKN et la BOD5 peuvent $\mathrm{e}^{\wedge}$ tre re' duits par une re' duction des TS dans les eaux use' es, il est important que les abattoirs enle 'vent le plus possible de TS de leurs eaux use' es. La pre' sence de sang a provoque' une augmenta-tion des niveaux de Co et de Mo dans les eaux use' es. Les concentrations de $11 \mathrm{me}^{\prime}$ taux pre' sents $\mathrm{e}^{\prime}$ taient tre ' $\mathrm{s}$ faibles et si les eaux use' es sont 'epandues de fac, on approprie' e, les risques pour l'environnement sont minimaux. Mots cle's: abattoir,'epandage, usine de transformation de viandes, eaux use' es.

\section{INTRODUCTION}

Waste materials generated from the slaughterhouse operations include inedible materials such as offal, hides, blood, wastewater, garbage from stomach and intestine and sanitary septage. Wastewater is generally collected in a retention tank beneath the kill floor, with storage capacity varying from plant to plant. Water is used for the scalding, chilling, dehairing, defeathering, washing and rinsing of carcasses, and the cleaning of processing equipment. Worldwide, slaughterhouses are facing the tasks of treat- ing and disposing of wastewater and residues (Munak 2002). Water consumption is dependent upon the type of animal slaughtered and processing operation. The wastewater may contain soil, animal fecal material, animal tissue, blood, hair/feathers and food grade cleaning agents. Worldwide legislations on regulating the disposal of slaughterhouse wastewater and solid waste are not yet uniform (Mittal 2007). European and North American regulations impose minimum land-application restrictions for water and soil protection (Mittal 2007). The Nutrient Management Act, 2002 (OMAFRA 2002), and subsequent modifications, prescribe standards for all land applied materials containing nutrients. To develop standards specific to land applied slaughterhouse wastes, there is a need to better understand the quality of the wastewater in terms of available $\mathrm{N}, \mathrm{P}, \mathrm{K}$ and toxicity.

There were 184 slaughterhouses and 60 free standing meat plants in Ontario licensed under the Food Safety \& Quality Act, 2001 (Government of Ontario 2001) as of January 23, 2006. All slaughter operations that are not federally registered must be licensed under this Act. Meat plants slaughtering and processing meat and meat products, are classified into two main plant categories - red meat and white meat. The water usage requirement varies with Massé and Masse (2000) reporting an average of 90 to $140 \mathrm{~L}$ per hog killed for slaughterhouses located in eastern Canada. Tritt and Schuchardt (1992) reported that slaughterhouses in Germany generated 200 to $600 \mathrm{~L}$ of wastewater per hog, and 1000 to $1500 \mathrm{~L}$ of wastewater per cattle. Stebor et al. (1990) reported that 400 to $3100 \mathrm{~L}$ of wastewater was generated per animal. In general, poultry slaughtering operations use more water, producing lower strength of the wastewater (Mittal 2004).

Presently, in Ontario, land application of wastewater generated from slaughterhouse falls under the Environmental Protection Act (OMAFRA 1996) and the determining factors for suitability are the same factors used for sewage, and pulp and paper biosolids. A system for treating high strength slaughterhouse wastewater (Rivera et al. 1997) consisted of an anaerobic digester followed by wetland using flow through the root zone of hydrophytes planted in a gravel substrate. The overall removal efficiencies were $88.5 \%$ for biological oxygen demand (BOD), $87.4 \%$ chemical oxygen demand (COD), $89 \%$ suspended solids (SS), $73.6 \%$ organic nitrogen and $>99 \%$ faecal coliforms. Therefore slaughterhouse wastewater is many times pre-treated before land application (Johns 1995; Mittal 2006). Pre-treatments are screening, catch basins, 
flotation, equalization, and settlers. About $40-60 \%$ of the solids or about $25-35 \%$ BOD load can be separated by screening and sedimentation (Mittal 2006).

Del Pozo et al. (2000) characterized poultry wastewater, and Massé and Masse (2000) characterized wastewater from hog slaughterhouses. Tritt and Schuchardt (1992) provided the wastewater characteristics for beef and hog separately. The strength and quantities of the wastewater vary from day to day, and from slaughterhouse to slaughterhouse as well. Since slaughterhouse wastewater has high chemical constituents loading and is made up of about $45 \%$ soluble and $55 \%$ coarse suspended organics (Nunez and Martinez 1999), some municipalities impose surcharges on treating slaughterhouse wastewater. Meat plant wastewater quality depends on water usage, type of animal slaughtered, and the amount of rendering or processing done on site (Mittal 2004). In Ontario and Quebec, Canada, slaughterhouse wastewater COD ranged from 2333 to $8627 \mathrm{mg} / \mathrm{L}$, and SS from 736 to $2099 \mathrm{mg} / \mathrm{L}$, volatile suspended solids (VSS) represented $80 \%$ of SS, and protein content from 444 to $2775 \mathrm{mg} / \mathrm{L}$. Slaughterhouse wastewater may contain several million colony forming units (cfu)/100 mL of total coliform, fecal coliform, and Streptococcus groups of bacteria (Mittal 2004).

Massé and Masse (2000) reported that one municipality calculated surcharges based on quantity of wastewater produced and treatment cost at the sewage treatment plant (STP), SS, BOD, fat oil and grease (FOG), nitrogen (N) and total phosphorus (TP). Another STP in south-western Ontario imposed their surcharge based on a 7 day rolling average of the BOD. Hence, BOD, TSS, FOG, N and P are some of the parameters to be monitored. Under the Environmental Protection Act, the monitoring of parameters such as BOD and SS are not required.

There has been some research completed to characterize the wastewater from slaughterhouse operations (Mittal 2004), however most of the data has been generated from large-scale operations and does not include all the parameters required to determine the suitability of the materials for land application. There is also an information gap on the level of 11 metals regulated under the Environment Protection Act (OMAFRA 1996), and the Nutrient Management Act, 2002. Therefore, the objective of this study involved collecting information representative of the Ontario slaughterhouses, relative to storage and disposal of wastewater, blood separation and wastewater handling practices. For this, a survey of provincial inspected slaughterhouses was also conducted, and wastewater was characterized after collecting samples.

\section{MATERIALS and METHODS}

\section{Survey}

A survey was conducted to determine meat plant wastewater disposal profiles of provincially-inspected slaughterhouses. The questionnaire included information such as species of animals slaughtered, average yearly slaughter rates, wastewater storage methods and holding capacity, methods currently used to handle wastewater, frequency of removal (if hauled), quantity of wastewater generally removed, and the method of final disposal by the hauler. One hundred and ninety survey questionnaires were sent out to effective slaughterhouses operating under the Meat Inspection Act (Ontario), and a total of 136 surveys were returned for an overall response rate of $70 \%$. Sixty-five percent of poultry slaughterhouses responded compared to $72 \%$ of red meat slaughterhouses. The high survey response rate was possible with the help of meat inspectors of OMAFRA.

Slaughterhouse wastewater samples were collected based on the type(s) of species slaughtered and the type of operation over an 18 month period. The categories of operations included: beef, hog, poultry, sheep and goat slaughter, and mixed species. Sampling sites were chosen based on the questionnaires completed in the profile component of the study. A minimum of 3 samples, each from different days of operations were collected from 6 slaughterhouses for each category of operation. All wastewater samples were collected at the end of the processing operation so that sample can represent day's wastewater.

\section{Sampling procedure}

Using the Nabber pole for average sample: One litre sterile bottle was attached to the end of a nabber pole. Nabber pole was dipped into the wastewater at the desired level. Wastewater was poured into sampling bucket once the jar was full. The total sample collected in the bucket should be representative of the wastewater in the entire retention tank. Therefore, samples were taken from a symmetrical pattern that covers the entire depth of the tank and as much of the width as possible. This continued until the sample bucket contained approximately $8 \mathrm{~L}$ of material.

Using the COLIWASA: The COLIWASA extension was attached where ceiling height permitted for tanks more than 6' deep. Ensuring that the stopper was disengaged, the COLIWASA was slowly lowered into the tank until it touched the bottom. The ball, attached to the end of the metal pole, was firmly pulled up to engage the stopper, then the COLIWASA was lifted out of the tank, and placed its bottom end in the sampling bucket. The stopper was released by pushing on the ball, allowing the COLIWASA to empty into the bucket. This was repeated until there was approximately $8 \mathrm{~L}$ of wastewater in the bucket.

Using a $1 \mathrm{~L}$ jar and a stir rod, the wastewater was transferred from the bucket to the sample jars. The depth of wastewater was recorded, and $\mathrm{pH}$, conductivity and dissolved oxygen (DO) levels in the wastewater were measured using the $1 \mathrm{~L}$ jar. Ten drops of nitric acid were added to two bottles for metal analysis, marking these with an (A) on the lid. The mercury analysis bottle (green lid) required 3 drops of acid and 3 drops of potassium (orange bottle). There were six $500 \mathrm{~mL}$ PET bottles, one $250 \mathrm{~mL}$ green-lidded glass jar for mercury analysis, and one $250 \mathrm{~mL}$ yellow-lidded glass jar for FOG analysis. Using bleach, water and a sponge, the sampling devices (COLIWASA or nabber pole), $1 \mathrm{~L}$ jar, sampling bucket and the exterior of each of the sample jars were cleaned. The sample jars were placed into a cooler with ice packs or ice. 


\section{Wastewater analysis}

Characterization included: $\mathrm{COD}, \mathrm{BOD}_{5}$, total solids (TS), total Kjeldahal nitrogen (TKN), ammonia and ammonium nitrogen, nitrite and nitrate nitrogen, total phosphorus, total potassium, total sodium, $\mathrm{pH}$, the 11 metals specified in the Ontario regulations (OMAFRA 1996), and FOG.

The samples were sent to the Ontario Ministry of the Environment (MOE) laboratory for analysis. All samples were put in an insulated styro-foam box and packed with icepacks. They were kept at or below $4{ }^{\circ} \mathrm{C}$. Once the laboratory received the samples, validated methods were used for the analyses. All methods used for the analysis of different parameters are listed in Table 1. The 11 metals that are regulated under the environment protection agency (EPA) and their prescribed limits are listed in Table 2. More details on regulations of these methods are given by Mittal (2007). These 11 metals were also analyzed from the wastewater samples obtained from slaughterhouses in Ontario. ANOVA with GLM procedures were used for the analysis of data, and the ranking of means was done using Duncan's procedure of Statistical Analysis System version 9.1 (SAS 2006). The independent variables were: Meat types - red and white, wastewater with and without blood, 7 sample locations, and commodity type - beef, pork, poultry, sheep/goat, mixed, and further processing. The dependent variables were chemical and biochemical parameters of the wastewater such as COD, FOG.

\section{RESULTS and DISCUSSIONS}

Table 3 provides typical operations for beef, hog and poultry processing. In a beef slaughterhouse, once the animal is rendered unconscious, operators will shackle the animal and hoist it to the bleeding rail. After the animal is stuck with a knife, blood will flow freely from the animal to the floor. In some slaughterhouses, there is a blood pit installed underneath the bleeding area to collect the blood. If a blood pit is not installed, the blood will drain and it will be mixed with the wastewater. In a small plant, when the beef cow stops bleeding, the operator will lower the animal onto a cradle (or dressing bed) for skinning. In a medium sized beef, the operator will install an automatic hide puller to remove the hide. The beef head removed from the carcass is washed and the nasal cavities are flushed with water. After the carcass is approved for human consumption, it will normally be split into two halves. A final rinse will be applied before the carcass is moved into the drip cooler. The carcass will stay in the drip cooler for approximately $24 \mathrm{~h}$ at $4^{\circ} \mathrm{C}$ to $10^{\circ} \mathrm{C}$ (Government of Ontario 2001).

In a hog slaughterhouse, animals are stunned electrically or with carbon dioxide, shackled separately onto a chain, bled and scalded whole at $60^{\circ} \mathrm{C}$ for $6 \mathrm{~min}$. The hog is then dehaired mechanically and by flame,and polished by hand or machine to remove any hair or charred particulates left on the carcass. After approval, the carcass is split into halves, rinsed and chilled to $4^{\circ} \mathrm{C}$ within $24 \mathrm{~h}$.

In a white meat slaughterhouse, birds are hanged onto a shackle, electrically stunned, slash the neck with a rotary disc, bled in a trough, scalded, defeathered and thoroughly rinsed. Besides opening up the carcass and presenting the viscera to the meat inspector for disposition, the carcasses can also be cut up prior to chilling. Legs, feet, wings, are some of the typical parts that are separated.

Water is used extensively for slaughtering operations after the stunning and killing processes. In a beef slaughterhouse, water is used for carcass washing after hide removal, evisceration, and final rinse. In hog slaughtering, water is used for scalding, dehairing, polishing, evisceration, washing and final rinse. In a poultry slaughterhouse, water is used for scalding, defeathering, evisceration, chilling and final rinse.

\section{Respondent profile component}

\section{Type of slaughter}

Forty-four slaughterhouses specialized in one specie. There were 8 beef, 10 pork, 22 poultry, 2 sheep and 2 rabbit slaughterhouses. The remaining 92 were mixed species slaughterhouses, for beef, pork, sheep, poultry, rabbit, elk, emu, ostrich, buffalo, deer, pigeons and quail. The size of the plants varied considerably, slaughtering

Table 1. Methods used for analyzing various slaughterhouse wastewater parameters.

\begin{tabular}{lcl}
\hline Method number & Equivalent APHA number & \\
\hline MOE-E3091 & 3114 & Parameters \\
MOE-E3181 & $3030 \mathrm{~F}$ & Calcium, chromium, cobalt, copper, lead, molybdenum, nickel, zinc \\
MOE-E3182 & $5010 \mathrm{~B}$ & BOD $_{5}$ \\
MOE-E3188 & $2540 \mathrm{~B}$ & Total solids \\
MOE-E3218 & $2510 \mathrm{~B}$ & Electrical conductivity, pH \\
MOE-E3246 & 5220 & COD \\
MOE-E3301 & $3112 \mathrm{~B}$ & Mercury \\
MOE-E3217 & $3111 \mathrm{~B}$ & Calcium, magnesium, sodium, potassium \\
MOE-E3366 & 4500 & Ammonia nitrogen, nitrite nitrogen, nitrite + nitrate nitrogen, phosphorus \\
MOE-E3368 & $4500 \mathrm{~N}_{\text {org }} \mathrm{D}$ & Total Kjeldahl nitrogen, total phosphorus \\
MOE* & $5520 \mathrm{D}$ & Fats, oils and greases \\
\hline
\end{tabular}

* = No method number assigned to this method; MOE = Ministry of Environment; APHA = American Public Health Association; Unit for all except EC and $\mathrm{pH}$ is $\mathrm{mg} / \mathrm{L}$. 
Table 2. Standards for regulated metals in materials applied to land that are not sewage biosolids (OMAFRA 1996).

\begin{tabular}{lccc}
\hline Regulated metals & $\begin{array}{c}\text { Maximum annual loading } \\
(\mathrm{kg} / \mathrm{ha} / \mathrm{yr})\end{array}$ & $\begin{array}{c}\text { Maximum cumulative } \\
\text { loading (kg/ha) }\end{array}$ & $\begin{array}{c}\text { Maximum concentration in materials } \\
\text { applied to land (mg/L) }\end{array}$ \\
\hline Arsenic & 0.28 & 1.4 & 1.70 \\
Cadmium & 0.05 & 1.6 & 0.34 \\
Cobalt & & 30.0 & 3.40 \\
Chromium & 4.70 & 210.0 & 28.00 \\
Copper & 2.70 & 150.0 & 17.00 \\
Mercury & 0.02 & 0.8 & 0.11 \\
Molybdenum & & 4.0 & 0.94 \\
Nickel & 0.70 & 32.0 & 4.20 \\
Lead & 1.80 & 90.0 & 11.00 \\
Selenium & & 2.0 & 0.34 \\
Zinc & 6.70 & 330.0 & 42.00 \\
\hline
\end{tabular}

anywhere from 50 to 550,000 animals per month (Fig. 1). The 112 slaughterhouses for red meat indicated numbers between 50 and 9,000 animals, with $63 \%$ slaughtering under 200 animals per month. The 22 poultry slaughterhouses slaughtered between 1,000 and 550,000 birds per month, with $60 \%$ of those slaughtering over 10,000 birds (Fig. 2).

\section{Blood collection}

When blood is collected during slaughtering, it reduces the BOD and odour. Sixty two percent surveyed slaughterhouses collected blood separately. Once the blood was collected, 74 of 85 slaughterhouses sent it to rendering and 11 composted blood on the premises.

\section{Wastewater}

Chill tanks are found only in poultry slaughterhouses. Scald tanks are used for poultry, pork and in some cases, sheep slaughterhouse as well. Thirty-six slaughterhouses surveyed had settling tanks pumped or skimmed out by renderers. This type of operation was more common for poultry. Two out of 136 plants surveyed utilized grease trap for fat separation. Out of 136 plants, $53 \%$ of them did not treat their wastewater prior to disposal (Fig. 3). Sixteen percent used treatment systems such as dissolved air floatation or aeration. The remaining $31 \%$ of slaughterhouses with a treatment utilized passive systems such as storage tank or lagoon to settle solids.

\section{Storage methods}

Six percent of the slaughterhouses did not store the wastewater and the drainage of these slaughterhouses were directly connected to the sewage treatment plant. Eighty percent of the slaughterhouses stored the wastewater in a retention tank prior to disposal and the remaining slaughterhouses stored the wastewater in lagoons or ponds. The sizes of these tanks varied from 3,000 to $750,000 \mathrm{~L}$.

\section{Method of disposal}

Fifteen percent of the slaughterhouses disposed the wastewater at the STP. Nine percent of the slaughterhouses were directly connected to the STP and $6 \%$ of them used a hauler to haul the wastewater to the STP. Eleven percent of the slaughterhouses used leaching bed for the disposal of the wastewater. An additional $21 \%$ used both the

Table 3. Typical beef, pork and poultry slaughtering processes.

\begin{tabular}{llll}
\hline Operation number & \multicolumn{1}{c}{ Beef } & \multicolumn{1}{c}{ Hog } & Poultry \\
\hline 1 & Receive live animals & Receive live animals & Receive live animals \\
2 & Stun & Hang & Stun \\
3 & Stick & Stick & Stick \\
4 & Shackle & Shackle & Scald \\
5 & Hoist & Hoist & Defeather \\
6 & Dehide & Scald & Rehang \\
7 & Hoist & Dehair & Eviscerate \\
8 & Eviscerate & Singe & Chill \\
9 & Final rinse & Polish & Chill \\
10 & Chill & Eviscerate & Package \\
11 & Cut \& debone & Final rinse & Ship \\
12 & Wrap & Chill & Cut \& debone \\
13 & Ship & Wrap & Ship \\
14 & & &
\end{tabular}




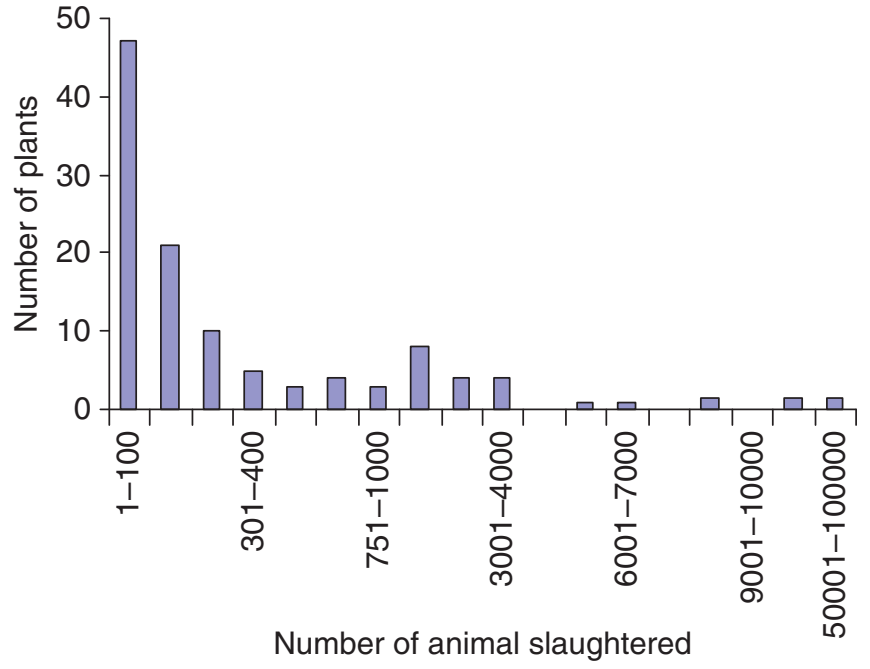

Fig. 1. Slaughter statistics per month for red meat and mixed slaughterhouses.

leaching bed and haulers to dispose of the wastewater. Forty three percent of the slaughterhouses land applied the wastewater. Of the $43 \%$ that land applied, $33 \%$ of them used hauler to land apply the wastewater. Fifty three percent of them land applied the wastewater on premises and the remaining $14 \%$ land applied elsewhere.

\section{Frequency of land application}

The frequency of land application varied from slaughterhouse to slaughterhouse and was mainly affected by the size of the storage facility and the slaughterhouse operating capacity. However, close to half of the slaughterhouses that land applied the wastewater stored the wastewater for no more than one month prior to land application (Fig. 4). This implied that these slaughterhouses land applied the wastewater year round.

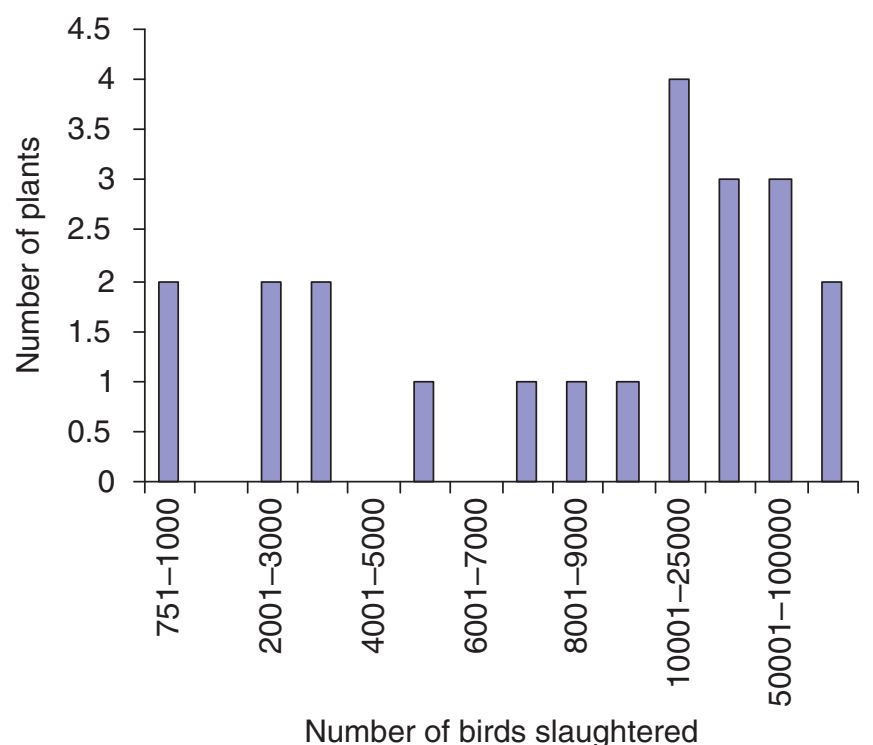

Fig. 2. Slaughter statistics per poultry slaughterhouses.

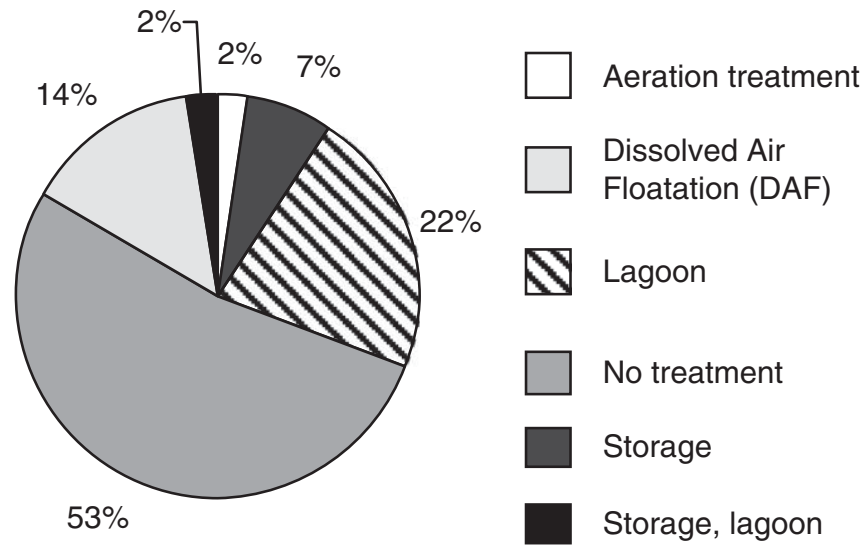

Fig. 3. Wastewater treatment methods used by slaughterhouses.

\section{Wastewater characterization}

There were 224 wastewater samples taken from 6 provincially licensed slaughterhouses at the time of study. The overall results are shown in Table 4, and Table 5 provides the results based on livestock type. Table 6 shows the ANOVA results. Results of these tables are discussed below.

\section{Total solids (TS)}

The overall mean TS was $6394 \pm 6625 \mathrm{mg} / \mathrm{L}$ and the overall median was $4500 \mathrm{mg} / \mathrm{L}$ (Table 4 ). The meat type and the presence of blood had a highly significant impact $(\mathrm{P}<0.0001)$ (Table 6). International studies (Mittal 2004) reported TS and VSS in the ranges of 220-6300 (highest in a study from Brazil) and 270-13411 mg/L (largest from a Nigeria study), respectively. Since the slaughterhouse wastewater contained bio-digestible materials such as

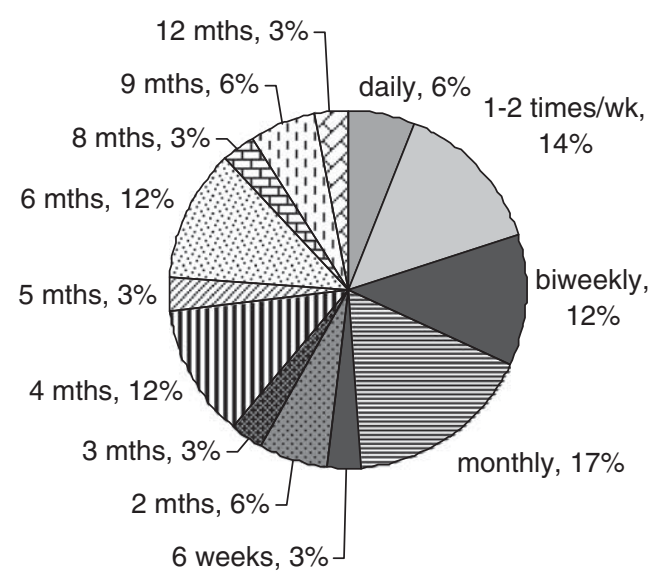

Fig. 4. Frequency of land application of wastewater by the slaughterhouse; mths $=$ months.

meat scrap and blood, removing these by screening and separate collection will reduce the TS and BOD loads and odours. Best management practices for solids management can remove manure from the floor before washing. The meat scraps can be disposed of by rendering, composting, 
Table 4. Meat plant wastewater results from selected provincially inspected slaughterhouses in Ontario $(\mathrm{MDL}=$ minimum detection limit).

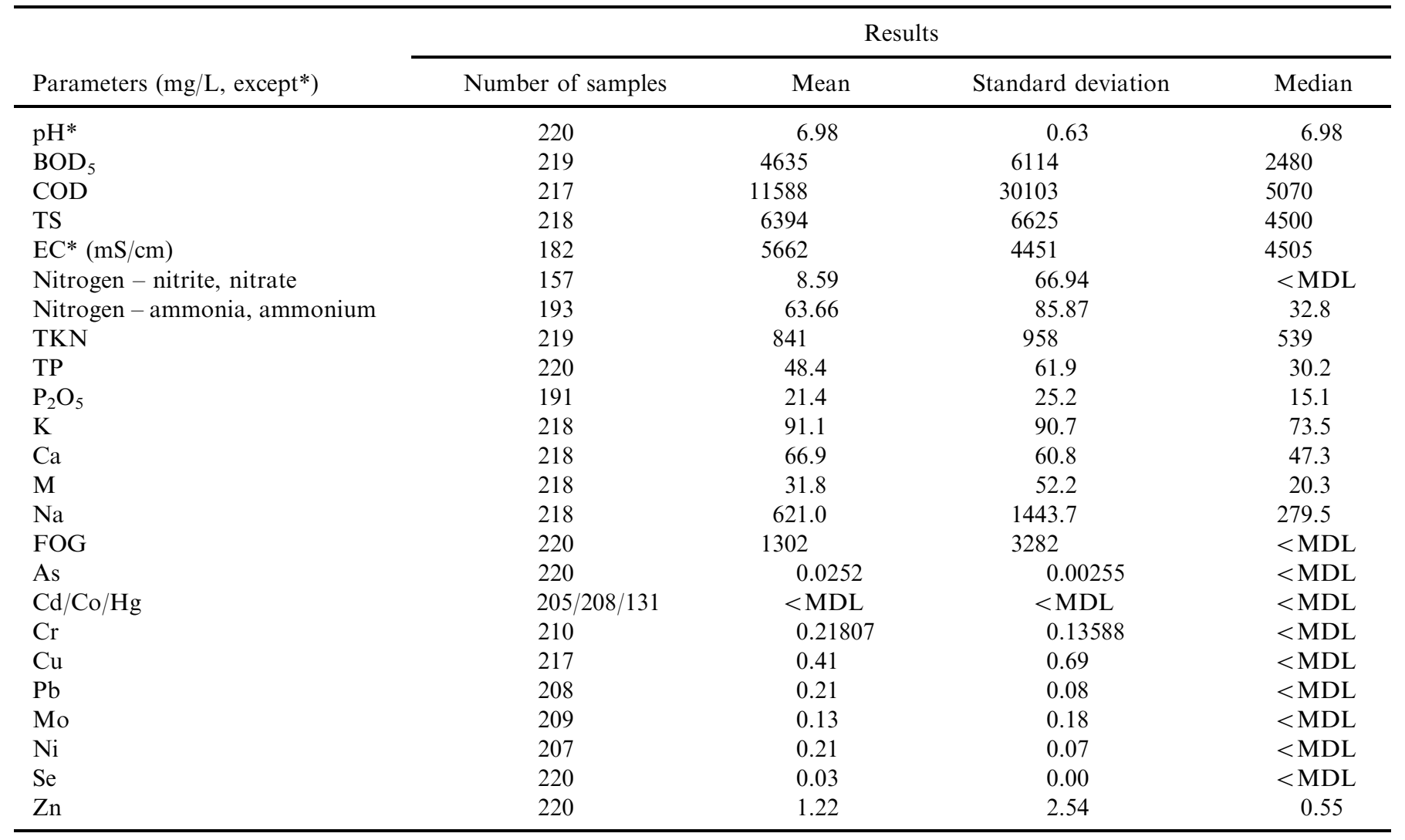

MDL for $\mathrm{Co}, \mathrm{Cr}, \mathrm{Cu}, \mathrm{Pb}, \mathrm{Ni}, \mathrm{Cd}, \mathrm{Zn}$ were $0.2 \mathrm{mg} / \mathrm{L}$, for $\mathrm{Hg}$ was 0.005 , for Se were 0.025 , for Mo was 0.1 , for $\mathrm{N}$ from nitrate and nitrite was 0.25 , and for FOG was $500 \mathrm{mg} / \mathrm{L}$.

burial or incineration instead of land application. This was dependent on how well the operators separated the meat scraps, manure, and blood from the wastewater. Hence, the separation of blood and improved handling of offal and manure are highly recommended for slaughterhouses that intend to land apply the wastewater.

Table 5. Meat plant wastewater results from six provincially inspected slaughterhouses in Ontario based on commodity and blood mixed with wastewater.

\begin{tabular}{|c|c|c|c|c|c|c|}
\hline Parameters & \multicolumn{6}{|c|}{ Values for wastewater with blood for different commodity } \\
\hline $\mathrm{BOD}_{5}$ & $14545 \pm 5802$ & $8231 \pm 9636$ & $4711 \pm 2356$ & $1648 \pm 859$ & $45 \pm 1$ & $6250 \pm 1796$ \\
\hline COD & $50665 \pm 83866$ & $15256 \pm 17072$ & $10010 \pm 6188$ & $3341 \pm 2234$ & $860 \pm 594$ & $9145 \pm 1351$ \\
\hline TS & $15694 \pm 6554$ & $9938 \pm 10107$ & $5862 \pm 2693$ & $2097 \pm 822$ & $1255 \pm 389$ & $8880 \pm 1725$ \\
\hline $\mathrm{N}^{\prime}$ & $116 \pm 170$ & $50 \pm 51$ & $43 \pm 96$ & $111 \pm 101$ & $0.4 \pm 0.2$ & $7 \pm 3$ \\
\hline TKN & $2310 \pm 1017$ & $1541 \pm 1454$ & $736 \pm 366$ & $432 \pm 199$ & $11 \pm 1$ & $927 \pm 1$ \\
\hline $\mathrm{TP}$ & $86 \pm 52$ & $77 \pm 96$ & $35 \pm 15$ & $34 \pm 14$ & $6 \pm 2$ & $82 \pm 50$ \\
\hline $\mathrm{P}_{2} \mathrm{O}_{5}$ & $47 \pm 19$ & $26 \pm 43$ & $15 \pm 7$ & $26 \pm 10$ & $2 \pm 1$ & $40 \pm 35$ \\
\hline $\mathrm{K}$ & $187 \pm 81$ & $110 \pm 76$ & $156 \pm 219$ & $66 \pm 33$ & $10 \pm 4$ & $130 \pm 56$ \\
\hline $\mathrm{Ca}$ & $48 \pm 25$ & $58 \pm 45$ & $76 \pm 48$ & $26 \pm 25$ & $19 \pm 13$ & $56 \pm 31$ \\
\hline
\end{tabular}

$\mathrm{N}=\mathrm{N}$ from Nitrate and nitrite, $\mathrm{N}^{\prime}=\mathrm{N}$ from ammonia and ammonium 
The overall mean $\mathrm{pH}$ was $6.98 \pm 0.63$ with a median of 6.98 (Table 4). This $\mathrm{pH}$ range is comparable to previous studies (6 to 10) (Mittal 2003, 2004). The minimum range is reported from Holland and Spain, and larger range from Germany and Newzealand. The $\mathrm{pH}$ was highly affected by the amount of chemicals used for cleaning and by water usage. The $\mathrm{pH}$ was significantly impacted by the sample location $(\mathrm{P}<0.05)$ (Table 6). The sample location could be the lagoon, the retention tank, or the holding tank. The age of the wastewater varied at these locations. The allowable $\mathrm{pH}$ range for wastewater discharge to the environment is usually around 6.5 to 8.5 (Tchobanoglous et al. 2003). With regards to land application, MOE determined the $\mathrm{pH}$ level of the material between 6.0 and 8.5 when it is applied to an established crop. Any material that has a $\mathrm{pH}$ level beyond the given range can be applied to agricultural land only before planting or after harvest, when crops are not present. The $\mathrm{pH}$ values obtained were within the range acceptable to MOE for land application to an established crop.

\section{Biochemical oxygen demand $\left(B O D_{5}\right)$}

In a pork slaughterhouse, water was used for scalding and dehairing whereas in a beef slaughterhouse, dehiding took the place of scalding and dehairing. The mean $\mathrm{BOD}_{5}$ value for pork wastewater samples was lower than the mean $\mathrm{BOD}_{5}$ value for beef because the overall water usage in the pork slaughterhouse was higher than in the beef (Table 4).

The overall mean $\mathrm{BOD}_{5}$ value was $4635 \pm 6114 \mathrm{mg} / \mathrm{L}$ with a median of $2480 \mathrm{mg} / \mathrm{L}$ (Table 4). The meat type, the presence of blood and the sample spot had a highly significant impact on the $\mathrm{BOD}_{5}(\mathrm{P}<0.0001)$ (Table 6). The BOD values reported by previous studies ranged from 199 to $4633 \mathrm{mg} / \mathrm{L}$ (Mittal 2003, 2004); however, not all authors reported $\mathrm{BOD}_{5}$ results. Lower range is provided by a study from Spain and larger ranges from Holland and India. Applying high $\mathrm{BOD}_{5}$ materials on the land surface may cause odour problems. The legislation in Ontario has not established a guideline for the acceptable $\mathrm{BOD}_{5}$ levels for material to be land applied. However, the issue of odour as a nuisance is addressed under the Environmental Protection Act.

The overall mean COD was $11588 \pm 30103 \mathrm{mg} / \mathrm{L}$ and the median was $5070 \mathrm{mg} / \mathrm{L}$ (Table 4). The COD from previous studies ranged from 530 to $11118 \mathrm{mg} / \mathrm{L}$ (Mittal 2003, 2004). Large ranges were provided from studies conducted in Canada and Holland. The meat type and the presence of blood had a significant impact at the $90 \%$ level on the COD. The $\mathrm{COD} / \mathrm{BOD}_{5}$ ratios for the different types of wastewater based on their mean values are given in Table 7. The $\mathrm{COD} / \mathrm{BOD}_{5}$ ratios of wastewater with blood were lower than the $\mathrm{COD} / \mathrm{BOD}_{5}$ ratios of wastewater without blood. It was caused by higher $\mathrm{BOD}_{5}$ level in wastewater with blood than wastewater without blood. The mean and median $\mathrm{COD} / \mathrm{BOD}_{5}$ ratios from all wastewater samples were 2.88 and 2.04 , respectively. The ratio also indicates that COD is much higher (1.49 to 4.80 times) than $\mathrm{BOD}_{5}$ for all wastewater. 
Table 7. COD/BOD 5 ratio based on commodity type.

\begin{tabular}{lcc}
\hline & \multicolumn{2}{c}{ COD $/$ BOD $_{5}$ ratio } \\
\cline { 2 - 3 } Commodity & Blood & No Blood \\
\hline Beef & 1.87 & 2.18 \\
Pork & 2.39 & 3.18 \\
Sheep & 1.49 & 2.15 \\
Mixed & 2.64 & 2.99 \\
Poultry & 2.19 & 4.80 \\
\hline
\end{tabular}

\section{Nitrogen}

The results for the analysis of various types of nitrogen were reported on the basis of nitrite nitrogen and nitrate nitrogen $\left(\mathrm{NO}_{2}-\mathrm{N}\right.$ and $\left.\mathrm{NO}_{3}-\mathrm{N}\right)$, ammonia and ammonium nitrogen $\left(\mathrm{NH}_{3}-\mathrm{N}\right.$ and $\left.\mathrm{NH} 4-\mathrm{N}\right)$, and total Kjeldahl nitrogen (TKN). The amount of nitrogen in the wastewater was affected by various factors (Tables 4 and 5). The presence of blood and the meat type had a highly significant impact on the TKN level $(\mathrm{P}<0.0001)$ (Table 6). Mittal (2003, 2004) reported wide variation in $\mathrm{TKN}$ and $\mathrm{NH}_{4} \mathrm{~N}$ in the ranges of $44-700 \mathrm{mg} / \mathrm{L}$ and $3-740 \mathrm{mg} / \mathrm{L}$, respectively. The sample spot had a highly significant impact on the amount of nitrite nitrogen and nitrate nitrogen in the wastewater $(\mathrm{P}<0.0001)$. The meat type and the commodity type had a significant impact on the ammonia nitrogen and ammonium nitrogen. Collecting the blood during slaughtering and reducing the amount of organics in the wastewater will reduce TKN. This can be achieved by precipitation of the solids in the wastewater followed by filtration (Mittal 2006).

The samples were taken from various locations such as septic tanks, total retention tanks, secondary tanks, ponds or lagoons just prior to land application. Different types of storage facilities provided different retention time. Some of the wastewater samples were taken immediately from the retention tank after the slaughtering was completed. Alternatively, the samples were taken from storage facility such as lagoon where the denitrification process had taken place to reduce the presence of nitrite and nitrate.

\section{Phosphorus and phosphate phosphorus $\left(\mathrm{P}_{2} \mathrm{O}_{5}\right)$}

Total phosphorus (TP) exists in wastewater as phosphate in the form of orthophosphate and polyphosphate. High amount of soluble orthophosphate is harmful to aquatic life. The mean and median TP for beef, sheep, mixed species and poultry wastewater with blood were higher than the samples without blood (Table 4). The mean TP of pork wastewater with blood was lower than without blood. The presence of blood and the meat type had a significant impact on the TP $(\mathrm{P}<0.05)$ (Table 6). The amount of phosphate phosphorus was not affected by the meat type, the presence of blood, the sample spot or the commodity type. Mittal $(2003,2004)$ reported phosphorous range of $6-175 \mathrm{mg} / \mathrm{L}$, and the largest range in the study was from Nigeria $(115-175 \mathrm{mg} / \mathrm{L})$.

\section{Potassium and sodium}

The presence of blood and sample spot had a highly significant impact on the potassium level $(\mathrm{P}<0.0001)$. The meat type had a significant impact as well $(\mathrm{P}<0.05)$ (Table 6). The mean sodium concentration was $621 \pm$ $1443 \mathrm{mg} / \mathrm{L}$ and the median was $280 \mathrm{mg} / \mathrm{L}$ (Table 4). The commodity type had a significant impact on the sodium level $(\mathrm{P}<0.05)$. The presence of blood, meat type and sample locations had no significant impact on the mean sodium value.

\section{Fat, oil and grease (FOG)}

Neither the meat type nor the commodity type had any impact on the level of FOG in the wastewater (Table 4). Mittal $(2003,2004)$ reported the largest range of FOG of 40-600 from a study from Brazil. The ANOVA with GLM results show that FOG was not affected by the sample location as well. The median FOG of beef and pork wastewater without blood was below minimum detection limit (MDL $=500 \mathrm{mg} / \mathrm{L}$ ), and with blood was $888 \mathrm{mg} / \mathrm{L}$ and MDL respectively. The median showed that FOG levels for the beef and mixed species wastewater with blood were higher than beef and mixed species wastewater without blood, but the presence of blood in wastewater had no significance on the FOG level.

\section{Electrical conductivity (EC)}

The average EC value was $5662 \pm 4451 \mathrm{mS} / \mathrm{cm}$, the median was $4505 \mathrm{mS} / \mathrm{cm}$, and the range was 1000 to $13000 \mathrm{mS} / \mathrm{cm}$ (Table 4). Only 5 wastewater samples had EC values $<1000 \mathrm{mS} / \mathrm{cm}$, and 43 samples had 1000 to $3000 \mathrm{mS} / \mathrm{cm}$. The median for pork wastewater without blood was $5185 \mathrm{mS} / \mathrm{cm}$ and with blood was $3340 \mathrm{mS} / \mathrm{cm}$. The meat type and commodity type had significant impact on the EC level $(\mathrm{P}<0.05)$ (Table 6). When blood was collected during the slaughtering, the mean EC of the beef was not significantly different than pork, sheep and mixed specie wastewater. However, when blood was not collected, the mean EC for beef wastewater with blood was significantly different than pork and poultry wastewater with blood. The mean EC for processing wastewater was lower from other types of wastewater. The EC provides information on soluble salts such as $\mathrm{K}, \mathrm{Mg}, \mathrm{Ca}$, and $\mathrm{Na}$. The presence of salts affects the water uptake efficiency of the crops. MOE and United States Environmental Protection Agency (USEPA) restrict the use of wastewater for irrigation when the EC is greater than $700 \mathrm{mS} / \mathrm{cm}$. Slaughterhouse wastewater is highly odorous and is therefore, not suitable for irrigation. Land application of high sodium wastewater is permitted only if the soil sodium and soil EC are monitored annually.

\section{Metals}

The presence of blood had a significant impact on the level of $\mathrm{Co}$ and $\mathrm{Mo}(\mathrm{P}<0.5)$. Unfortunately, blood samples from animals slaughtered were not taken from those slaughterhouses. Hence, the level of Co and Mo might be affected by other environmental factors such as the type of stainless steel being used in the slaughterhouses or the Co or Mo level in the water used. The meat type had a 
significant impact on the level of $\mathrm{Cr}(\mathrm{P}<0.05)$ (Table 6). Other metals levels are not affected by any independent variable studied (Table 6). Not much data is available on these metals in the literature. Since no meat tissue samples were taken when the wastewater samples were taken, it can not conclusively suggest that meat tissues contained any metals. The level of metals in the slaughterhouse wastewater samples are shown to be lower than the limits stipulated under the legislation in Ontario. Metal behaviour in soils and plant uptake is difficult to generalize. If a more precautionary approach to toxic metal addition to the soil is to be taken, studies of the behaviour of each metal in each specific situation would have to be performed. Land application of wastewater is a common practice by slaughterhouse operators. Several larger slaughterhouses have approvals from the MOE to land apply the wastewater on agricultural land.

\section{Overall results and further work}

Overall, based on the ANOVA with GLM results, the meat type had a highly significant impact on the $\mathrm{BOD}_{5}$, TKN, and TS $(\mathrm{P}<0.0001)$ and a significant impact on the $\mathrm{Cr}$, ammonia and ammonium nitrogen, $\mathrm{TP}, \mathrm{K}$ and $\mathrm{EC}$ $(\mathrm{P}<0.05)$. The presence of blood had a highly significant impact on the $\mathrm{BOD}_{5}, \mathrm{TKN}, \mathrm{K}$ and TS $(\mathrm{P}<0.0001)$ and a significant impact on Co, Mo, and TP $(\mathrm{P}<0.05)$. The commodity type had a significant impact on the $\mathrm{BOD}_{5}$, ammonia and ammonium nitrogen, TKN, TS, EC and Na $(\mathrm{P}<0.05)$. The sample location had a highly significant impact on the nitrite nitrogen and nitrate nitrogen, and $\mathrm{K}$ $(\mathrm{P}<0.0001)$ and a significant impact on the $\mathrm{pH}(\mathrm{P}<0.05)$ (Table 6).

There are concerns about the presence of pathogenic microorganisms in slaughterhouse wastewater. There are also concerns about the odour that may be generated from land applying the wastewater. These two topics should be further investigated and quantified. Further studies should also be conducted to evaluate the performance and economic impact of various types of wastewater treatment methods. Mittal $(2003,2004)$ reviewed the work conducted in these areas around the World. Limited data is available on pathogens in slaughterhouse wastewater. However slaughterhouse wastewater may acquire pathogens naturally from hides and digestive tracts of the slaughtered animals. Few countries have provided acceptable pathogens levels in wastewater for land application. France and Italy allow spreading of biosolids containing up to 0.8 and 1000 most probable number (MPN) of Salmonella per $\mathrm{g}$ of dry matter respectively. Regulations are proposed for Entrovirus, Entrobacteria, and parasites in some countries.

\section{CONCLUSIONS}

The meat type had a highly significant impact on the $\mathrm{BOD}_{5}, \mathrm{TKN}$, and TS and a significant impact on the $\mathrm{Cr}$, ammonia and ammonium nitrogen, TP, K and EC. The presence of blood had a highly significant impact on the $\mathrm{BOD}_{5}, \mathrm{TKN}, \mathrm{K}$ and TS and a significant impact on Co, Mo, and TP. The commodity type had a significant impact on the $\mathrm{BOD}_{5}$, ammonia and ammonium nitrogen, TKN, $\mathrm{TS}$, EC and $\mathrm{Na}$. The sample spot had a highly significant impact on the nitrite nitrogen and nitrate nitrogen, and $\mathrm{K}$ and a significant impact on the $\mathrm{pH}$.

As the TKN and the $\mathrm{BOD}_{5}$ can be decreased by the reduction of TS in the wastewater, it is important that the slaughterhouses remove as much total solids from the wastewater as possible. This will reduce the odour and the impact on the environment. The concentration of heavy metals present in slaughterhouse wastewater is very low. The blood significantly increased the $\mathrm{Co}$ and $\mathrm{Mo}$ levels in the wastewater.

\section{LIST OF SYMBOLS}

$\begin{array}{ll}\text { ANOVA } & \text { Analysis of variance } \\ \text { BOD or BOD } 5 & \text { Biochemical oxygen demand } \\ \text { CFIA } & \text { Canadian Food Inspection Agency } \\ \text { DO } & \text { Dissolved oxygen } \\ \text { COD } & \text { Chemical oxygen demand } \\ \text { EC } & \text { Electrical conductivity } \\ \text { EPA } & \text { Environmental Protection Act, R.R.O. } \\ & 1990 \\ \text { FOG } & \text { Fats, oils and greases } \\ \text { GLM } & \text { General linear modeling } \\ \text { MDL } & \text { Minimum detection limit } \\ \text { MOE } & \text { Ontario Ministry of the Environment } \\ \text { MPN } & \text { Most probable number } \\ \text { OMAF } & \text { Ontario Ministry of Agriculture and } \\ \text { OMAFRA } & \text { Food } \\ \text { SAS } & \text { Ontario Ministry of Agriculture, Food } \\ \text { SS } & \text { and Rural Affairs } \\ \text { STP } & \text { Statistical Analysis System } \\ \text { TDS } & \text { Soluble solids } \\ \text { TKN } & \text { Sewage treatment plant } \\ \text { TP } & \text { Total dissolved solids } \\ \text { TS } & \text { Total Kjeldahl nitrogen } \\ \text { TSS } & \text { Total phosphorus } \\ \text { USEPA } & \text { Total solids } \\ \text { VSS } & \text { Total suspended solids } \\ & \text { United States Environmental Protection } \\ \text { Agency } \\ \text { Volatile suspended solids }\end{array}$

\section{REFERENCES}

del Pozo, R., V. Diez and S. Beltran. 2000. Anaerobic pretreatment of slaughterhouse wastewater using fixedfilm reactors. Bioresource Technology 71: 143-149.

Government of Ontario. 2001. Food Safety and Quality Act. Toronto, ON: Government of Ontario.

Johns, M.R. 1995. Developments in wastewater treatment in the meat processing industry: a review. Bioresource Technology 54: 203-216.

Massé, D.I. and L. Masse. 2000. Characterization of wastewater from hog slaughterhouses in eastern Canada and evaluation of their in-plant wastewater treatment systems. Canadian Agricultural Engineering 42(3): 139-146. 
Mittal, G.S. 2003. Characterisation of the effluent wastewater from provincially licensed meat plants (abattoir) - Review. Unpublished report. Toronto, ON: Ontario Ministry of the Environment.

Mittal, G.S. 2004. Characterization of the effluent wastewater from abattoirs for land application. Food Review International 20: 229-256.

Mittal, G.S. 2006. Treatment of wastewater from abattoirs before land application - a review. Bioresource Technology 97: 1119-1135.

Mittal, G.S. 2007. Regulations related to land-application of abattoir washwater and residues. Agricultural Engineering International 9: 1-37.

Munack, A. 2002. Agriculture and the environment: new challenges for engineers. Agricultural Engineering International 4: 1-8.

Nunez, L.A. and B. Martinez. 1999. Anaerobic treatment of slaughterhouse wastewater in an expanded granular sludge bed (EGSB) reactor. Water Science Technology 40(8): 99-106.

OMAFRA. 1996. Guidelines for the Utilization of Biosolids and other Wastes on Agricultural Land. http:// www.ene.gov.on.ca/environment/en/resources/STD01_ 076424.html (2011/02/15).
OMAFRA. 2002. The Nutrient Management Act. http:/ www.e-laws.gov.on.ca/html/statutes/english/elaws_statutes_ 02n04_e.htm $(2006 / 10 / 10)$.

Rivera, F., A. Warren, C.R. Curds, E. Robles, A. Gutierrez, E. Gallegos and A. Calderon. 1997. The application of the root zone method for the treatment and reuse of high-1;strength abattoir waste in Mexico. Water Science \& Technology 35(5): 271-278.

SAS. 2006. Statistical Analysis System, version 9.1. Cary, NC: Statistical Analysis System Institute Inc.

Stebor, T. W., C.L. Berndt, S. Marman and R. Gabriel. 1990. Operating experience: anaerobic treatment at Packerland Packing, Lewis. In: Proceedings of the 44th Purdue Industry Waste Conference, 825-834. Chelsea, MI. May 9-11.

Tchobanoglous, G., F. Burton and H.D. Stensel. 2003. Wastewater Engineering: Treatment and Use. 4th Edition. New York, USA: MGraw Hill.

Tritt, W.P. and F. Schuchardt. 1992. Materials flow and possibilities of treating liquid and solid wastes from slaughterhouses in Germany: a review. Bioresource Technology 41: 235-245. 